Article

\title{
Family Forest Owners' Perception of Management and Thinning Operations in Young Dense Forests: A Survey from Sweden
}

\author{
Thomas Kronholm *, David Bengtsson and Dan Bergström \\ Department of Forest Biomaterials and Technology, Swedish University of Agricultural Sciences, \\ 90183 Umea, Sweden; da_bengt@hotmail.com (D.B.); dan.bergstrom@slu.se (D.B.) \\ * Correspondence: thomas.kronholm@slu.se; Tel.: +46-72-239-4985
}

Received: 28 September 2020; Accepted: 29 October 2020; Published: 30 October 2020

check for updates

\begin{abstract}
Family forest owners (FFOs) own 48\% of Sweden's productive forest land and are responsible for $59 \%$ of the annual gross felling. They are thus important suppliers of raw materials to the forest industry and the energy sector. Environmental goals on the national and international level promote an increased use of renewable resources in order to replace fossil-based fuels, but since the current supply of forest products is already fully utilized by the industry, there is a need to find new types of biomass assortment. One way to increase the biomass supply is to replace traditional pre-commercial thinning operations, where fallen stems are left in the forest to rot, with whole-tree harvesting of small-diameter trees using novel technologies and methods. This will however require willingness of the FFOs to shift their management practices. The objectives of this study were, therefore, to elucidate FFOs' perceptions of management and thinning operations in young dense forests, identify if there are differences depending on their demographic backgrounds, and clarify which factors could potentially affect their willingness to implement whole-tree harvesting in young dense forests. Data were collected through a survey administered to a random sample of 842 FFOs, with a response rate of $53.4 \%(n=450)$. The results show that FFOs in general are positive towards implementing whole-tree harvesting in young dense stands, and are often also willing to promote the development of suitable stands. Factors such as forest size, geographical location, distance from home to their forest, degree of self-employment and current need for cleaning were found to significantly affect their attitudes. The study highlights that the development of cost efficient harvesting techniques and working methods is important if the industry wants to increase the FFOs' willingness to engage in whole-tree harvesting in young dense forest stands and thereby increase the supply of biomass.
\end{abstract}

Keywords: harvesting; biomass; bioenergy; attitudes; small-scale forestry

\section{Introduction}

In Sweden, 320,000 family forest owners (FFOs) own more than 11 million hectares (ha) of productive forests, which corresponds to $48 \%$ of the country's productive forestland [1]. FFOs are important suppliers of raw materials to the forest industry and the energy sector, as 53 million cubic meters (59\% of national gross felling) were harvested in forests owned by FFOs in 2017 [2]. A large share of the harvested volume consists of roundwood delivered to sawmills and pulp mills, but logging residues (mainly tops and branches from clear cuts) are, along with e.g., forest industrial waste streams such as bark, saw-dust etc., also utilized for heat and power generation. In 2017, bio-fuels represented $25 \%$ of the total supply to energy production, of which $80 \%$ were forest-based fuels; indeed, during the last 30 years the use of forest-based fuels for this purpose has increased steadily [3]. Both national and international environmental goals promote this development [4], as fossil-based fuels need to be 
replaced by renewable resources in order to reach future targets. However, although studies have shown that a larger proportion of logging residues (including stumps and roots) could be extracted from forests in a sustainable way, other studies indicate that this alone will not be enough to cover future demand for biomass $[5,6]$. Furthermore, since the current supply of forest products is fully utilized by the industry, new types of biomass assortments might be needed to meet this increased demand.

One way to increase the available biomass volume is to utilize small, non-commercial sized trees from young dense forests $[7,8]$. In this context, these are defined as stands with a density of approximately $3500 \mathrm{stems} / \mathrm{ha}$ and an average stem size of maximum $10 \mathrm{~cm}$ diameter over bark at breast height (DBH). Fernandez-Lacruz et al. [8] highlight that: (1) biomass-dense thinning forests cover 2.1-9.8 million ha in Sweden (representing 9-44\% of the country's productive forest land area, depending on the constraints applied); (2) $65 \%$ of this forest area is located in northern Sweden; and (3) there is a yearly harvesting potential of at least 4.3 million oven-dry (OD) tonnes $(t)$ of undelimbed whole trees (3.0 million OD $t$ of delimbed stemwood including tops). Hence, the idea is to utilize the biomass production in the early stages of a stand rotation by changing the typical pre-commercial thinning operation, where the fallen stems are just left in the forest to rot, by using novel methods and technologies to harvest the small-diameter trees for bioenergy purposes, for example [7,9-13].

The willingness of Swedish FFOs to change their management of young forests (i.e., in stands that are suitable for biomass harvest) for this purpose has until now however not been investigated, and, therefore, they are potential key sources of forest biomass. Investigating this is very important in order to direct further research and development work in forest management towards reaching the environmental goals that have been set. The average forest property owned by a FFO is 78 ha and has a value of approximately 200,000 euros (with significant regional variations), and for many the forest may thus be a significant investment because in 2010 the median annual income for wage earning FFOs was 31,000 euros and for pensioners it was 16,900 euros [14]. An increased utilization of the biomass that today is seldom extracted and sold from early (pre-commercial) thinnings could thus be interesting for many FFOs. However, since FFOs are heterogeneous in terms of management objectives, education, forest values, dependency on forest income, residency etc. [14-17], it could be expected that management attitudes and behaviors differ between groups. Earlier studies have, for example, shown differences between male and female owners' harvesting activity, and also that those who place a high value on recreation tend to harvest less than multi-objective owners and self-employed owners $[18,19]$. Differences in values and management attitudes have also been found between resident and non-resident owners [15]. The objectives of this study were, therefore, to elucidate FFOs' perceptions of management and thinning operations in young dense forests, identify whether there are differences depending on their demographic backgrounds, and clarify which factors could potentially affect their willingness to implement this particular management practice in their own forests.

\section{Materials and Methods}

\subsection{Sample}

The sampling process was administered by the Swedish mapping, cadastral and land registration authority (Lantmäteriet), based on guidance from the authors. The sample was selected from all owners within a cadastral who were registered as such on 1 January 2019. However, owners with forest properties smaller than 6 ha were excluded as they make up a large proportion of FFOs (about one third) but in total own just 3\% of Sweden's forestland [1]. The reason was to avoid a large proportion of the owners participating in the study representing management views and practices that affect only a limited area of Swedish forests and their associated biomass. With this restriction, a random sample of 1000 FFOs was selected. The sample size was determined by calculating that the recommended number of responses needed for a representative sample was 384 [20,21], and then taking into account that similar surveys in Sweden have reached a response rate of $40-50 \%[15,22]$. 
The information collected from the cadastral data was: forest owner's name, address, personal identity code, total amount of productive forestland owned (ha) and county in which the largest forest holding was located. The initial sample contained 158 individuals residing outside Sweden and these were removed for two reasons: the questionnaire was only available in Swedish, and it was considered that there were too many practical difficulties in conducting a mail survey internationally in relation to the resources available for the study. Therefore, the final sample consisted of 842 individuals. The gender distribution was $64 \%$ males and $36 \%$ females, which is similar to the distribution in the studied population. However, a significant geographical concentration to the country's southern region was identified in the sample (Table 1). As a result of this, the Norrland region, which represents more than half of Sweden's land area, could not be split into two smaller regions as planned. To investigate differences between regions was of interest since they differ in terms of growth conditions, property values, population density, tree species composition, availability of biomass-dense forests [8] and similar factors that might affect the market conditions and thus also the attitudes of FFOs.

Table 1. Number and proportion of family forest owners (FFOs) in the sample in each region. For comparison, the geographical distribution of all Swedish owners (including those with properties $<6$ ha) is also presented.

\begin{tabular}{cccc}
\hline Region & $\begin{array}{c}\text { Number } \\
\text { of FFOs }\end{array}$ & $\begin{array}{c}\text { Share of Total } \\
\text { Sample (\%) }\end{array}$ & $\begin{array}{c}\text { Geographical Distribution of } \\
\text { All FFOs in Sweden (\%) }\end{array}$ \\
\hline Götaland (Southern Sweden) & 668 & 79.3 & 41.0 \\
Svealand (Central Sweden) & 138 & 16.4 & 31.5 \\
Norrland (Northern Sweden) & 36 & 4.3 & 27.5 \\
\hline
\end{tabular}

\subsection{Data Collection}

A questionnaire consisting of 19 questions was constructed for data collection (Table 2). The first part of the questionnaire covered FFOs' background information such as age, gender, duration of forest ownership, distance between the owners' home and the forest, and what type of forest management activities the owners carried out by themselves. The respondent was also asked to rank the parameters "economic return", "recreation" and "nature conservation" according to their importance for their management objectives. The second part of the questionnaire contained questions regarding management of young dense forest stands. The method of whole-tree harvesting in young dense forest stands was briefly explained, and the FFOs were asked if they were already familiar with this specific thinning method, whether they had conducted thinning using this method, and if they currently had the type of forest where thinning would be needed. Given three different scenarios about the economic consequences of using the methods, they were also asked about the likelihood that they would conduct a thinning under those circumstances. The scenarios were that: (a) the cost of the thinning operation would be higher than the income from the sales of the biomass, but not more costly than a traditional cleaning before thinning; (b) the cost would be equal to the income; and (c) the income would be higher than the cost. In the latter two scenarios, it was also stated that the cost for traditional cleaning before thinning would be avoided. All three scenarios were given with the caveat that it would not affect future income in any way. Finally, the respondents were asked about different factors that could potentially affect their attitude towards this specific method in a negative way. The factors were defined based on the literature and previous experiences from similar projects. However, in the concluding question the respondents could also freely share their views on whole-three harvesting or this particular survey, but the majority gave no response on this question. The ones who answered it mainly elaborated on their previous answers or their general views on forest management. 
Table 2. Questions and response alternatives in the questionnaire (translated from Swedish).

\begin{tabular}{|c|c|}
\hline Question & Response Alternatives \\
\hline 1. Are you ...? & Male; Female \\
\hline 2. How old are you? & Years? \\
\hline 3. How many hectares of productive forest is your forest property? & $0-50$ ha; 5-200 ha; >200 ha \\
\hline 4. In which part of the country is the main share of your forest located? & $\begin{array}{l}\text { Götaland; Svealand; Southern } \\
\text { Norrland; Northern Norrland }\end{array}$ \\
\hline 5. How far from the forest property is your residence? & $<30 \mathrm{~km} ; 30-100 \mathrm{~km} ;>100 \mathrm{~km}$ \\
\hline 6. How long have you been a forest owner? & $<5$ years; $5-10$ years; $>10$ years \\
\hline 7. Are you a member of a forest owners' association? & Yes; No \\
\hline $\begin{array}{l}\text { 8. Rank the following parameters from } 1 \text { to } 3 \text { according to your own } \\
\text { priorities for the forest property }\end{array}$ & $\begin{array}{l}\text { Economic return; recreation; } \\
\text { nature conservation }\end{array}$ \\
\hline $\begin{array}{l}\text { 9. How do you perform the following management activities on your } \\
\text { property? Planting; Cleaning; Thinning; Wind-throws and insect } \\
\text { damages; Other activities (e.g., final-felling and soil scarification) }\end{array}$ & $\begin{array}{l}\text { I do everything myself; I do } \\
\text { part of the work myself; I } \\
\text { always hire someone for it; Not } \\
\text { performed during my time } \\
\text { as owner }\end{array}$ \\
\hline 10. Are you familiar with the whole-tree harvesting method? & Yes; No \\
\hline 11. Have you done a whole-tree harvesting on your forest property? & Yes (years ago?); No \\
\hline $\begin{array}{l}\text { 12. Are there currently areas on your forest property that are in } \\
\text { imminent need of cleaning or thinning? }\end{array}$ & Yes; No; Do not know \\
\hline
\end{tabular}

13. Would you do a whole-tree harvest if it results in a negative net result (the income from the biomass sales is less than the work cost), but not more costly than what a traditional cleaning operation before thinning would be? Assume that the result of later measures (thinning $\mathcal{E}$ final-felling) is not affected.
14. Would you do a whole-tree harvest if it results in a zero net result (the income from the biomass equals the work cost), but you avoid the cost for traditional cleaning operations before thinning? Assume that the result of later measures (thinning $\mathcal{E}$ final-felling) is not affected.

15. Would you do a whole-tree harvest if it results in a positive net result (the income from the biomass is larger than the work cost), but you avoid the cost for traditional cleaning operations before thinning? Assume that the result of later measures (thinning $\mathcal{E}$ final-felling) is not affected.

16. Can you imagine yourself to, on parts of your forest property, actively reduce the number of cleanings and/or to clean less intensely (leave more stems) to develop areas suitable for whole-tree harvesting?

17. Would a recommendation from a timber buyer/forester imply that you, in suitable areas, would choose whole-tree harvesting instead of traditional thinning with pre-cleaning.
Yes, absolutely; Yes, in some cases; No, probably not; No, absolutely not

Yes, absolutely; Yes, in some cases; No, probably not; No, absolutely not

Yes, absolutely; Yes, in some cases; No, probably not; No, absolutely not

Yes, absolutely; Yes, in some cases; No, probably not; No, absolutely not

Yes, absolutely; Yes, in some cases; No, probably not; No, absolutely not

18. Research on whole-tree harvesting is on-going. If research results would show any of the following consequence, to what extent would it influence your opinion about whole-tree harvesting negatively? Access roads need to be made earlier than for traditional thinning; Causes a temporary decrease in future growth compared to traditional thinning; Decreases the future timber volume compared to traditional thinning;

Causes more soil damage than traditional thinning; Causes more damage to remaining trees compared to traditional thinning; It leaves more understory vegetation than traditional thinning with pre-cleaning; It is an untested method
No influence; Minor negative influence; Negative influence; Strong negative influence; Unable to say

19. Do you have any additional remarks about whole-tree harvesting or this survey that you wish to share?

Open 
The proposed questions were tested on a small group of FFOs, forestry students, and individuals with no forestry background to ensure that they were clear and correctly understood. Minor changes were made thereafter based on the feedback received.

The questionnaire was sent out to FFOs by traditional mail in October 2019. A couple of weeks after the first mailing, a reminder was sent out to those who had not yet responded. In both mailings the FFOs received the questionnaire together with an envelope that allowed them to return it, once completed, free of charge. The final response rate was $53.4 \%(n=450)$. Some FFOs informed us that they felt unable to complete the questionnaire because of illness, or they were no longer forest owners, or that they considered themselves to have too little knowledge about forestry to answer the questions properly.

\subsection{Analysis}

The collected data was analyzed with the IBM (Armonk, NY, USA) SPSS Statistics (version 26) software. For analyses of differences between groups, $\chi^{2}$ or $t$-tests were used.

When applicable, the responses alternatives "yes, absolutely" and "yes, in some cases" were combined and coded as "positive" responses, and similarly the alternatives "no, absolutely not" and "no, probably not" were combined to represent "negative" responses to the specific question. This was done since the number of responses in the extremes was sometimes very low. Further, the respondents were classified based on their level of self-employment. If they did all work themselves on at least two of the suggested activities (Table 2, question 9), and in total performed some work themselves on four out of five items, they were classified as self-employed. Those who did not qualify for the self-employed group but did all or parts of the work themselves on at least two items were classified as partly self-employed. All others were classified as passive.

The three survey questions on FFOs' attitudes towards whole-tree harvesting that included scenarios (Table 2, questions 13-15) were considered to be of similar nature, as they only differed on economic outcome; thus, in order to analyze and report differences between groups in a rational and comprehensible way, they were combined to represent the respondent's overall attitude. This was achieved by assigning respondents who had given a positive answer to at least two out of three scenarios to a positive group, and all others to a negative group. This was deemed to give a more accurate representation of their overall attitude rather than calculating a mean score for their answers, as a response in the extreme could skew the overall score in a misleading way.

The participation bias analysis showed that female owners had a significantly lower response rate than male owners $\left(\chi^{2}\right.$-test, $\left.p=0.024\right)$. The response rate for females was $45 \%(n=139)$ and for male owners $58 \%(n=311)$. No significant difference was found between participants and non-participants with respect to mean forest size owned ( $t$-test, $p=0.319$ ). However, owners with medium-size properties (51-200 ha) were significantly more likely to respond than those with small properties (Table 3) $\left(\chi^{2}\right.$-test, $\left.p=0.000\right)$. As shown in Table 4 , the responses from different regions reflected the proportions in the sample and no significant difference was found $\left(\chi^{2}\right.$-test, $\left.p=0.125\right)$.

Table 3. Number of respondents according to size of forest holding, compared to the expected number of responses if they had been randomly distributed. Information was missing for one respondent.

\begin{tabular}{cccc}
\hline Forest Size (ha) & Respondents & Expected & Residual \\
\hline$\leq 50$ & 268 & 331 & -63 \\
$51-200$ & 156 & 102 & 55 \\
$>200$ & 25 & 17 & 8 \\
\hline
\end{tabular}

Table 4. Number of respondents according to region, compared to the expected number of responses if they had been randomly distributed. Information was missing for one respondent.

\begin{tabular}{cccc}
\hline Region & Respondents & Expected & Residual \\
\hline Götaland & 351 & 356 & -5 \\
Svealand & 70 & 74 & -4 \\
Norrland & 28 & 19 & 9 \\
\hline
\end{tabular}




\section{Results}

\subsection{Description of Respondents}

The mean age of the respondents was 64 years and there was no significant difference between males and females. Most of them (84\%) had owned their forest for more than 10 years, and only 5\% had been forest owners for less than 5 years. The average forest size was 69 ha. No significant difference was found between male and female owners concerning forest size ( $t$-test, $p=0.211$ ), although the average for male owners was 74 ha and 58 ha for female owners. Three out of four respondents (75\%) lived nearer to their forest than $30 \mathrm{~km}$, while 15\% lived more than $100 \mathrm{~km}$ away from their forest.

The majority of owners ranked economic returns as their most important management objective (Table 5). Small, but not significant $\left(\chi^{2}\right.$-test, $\left.p=0.282\right)$, gender differences could be identified, as a slightly larger proportion of female owners considered recreation or nature conservation to be their top priority.

Table 5. Forest owners' most important management objective $(n=432)$.

\begin{tabular}{cccc}
\hline Top Ranked Objective & Males (\%) & Females (\%) & Total (\%) \\
\hline Economic return & 55 & 47 & 53 \\
Recreation & 26 & 28 & 26 \\
Nature conservation & 19 & 24 & 21 \\
\hline
\end{tabular}

The proportions who were members or not of forest owners' associations was almost equal, with $49 \%$ being members. Compared to non-members, a significantly higher proportion of members ranked economic return as their most important objective (Table 6) $\left(\chi^{2}\right.$-test, $\left.p=0.005\right)$.

Table 6. Percentage of forest owners' association members' and non-members' ranking economic return, recreation or nature conservation as the most important management objective $(n=431)$.

\begin{tabular}{cccc}
\hline Membership & Economic Return (\%) & Recreation (\%) & Nature Conservation (\%) \\
\hline Yes & 61 & 22 & 17 \\
No & 45 & 30 & 25 \\
\hline
\end{tabular}

As shown in Table 7, the majority of the respondents were active owners who performed all or parts of the work related to planting, cleaning, and handling of wind-throws or insect damage. Typically, these activities involve manual or motor-manual work. It was more common that respondents hired external labor for thinning and other activities, such as final felling and soil scarification, that are normally carried out with forest machinery.

Table 7. Percentage of forest owners who take care of the management activities themselves or hire contractors for all or parts of the work.

\begin{tabular}{ccccc}
\hline Activity & $\begin{array}{c}\text { I Do All Work } \\
\text { by Myself (\%) }\end{array}$ & $\begin{array}{c}\text { I Do Parts of the } \\
\text { Work Myself (\%) }\end{array}$ & $\begin{array}{c}\text { I Always Hire } \\
\text { Someone to Do } \\
\text { the Work (\%) }\end{array}$ & $\begin{array}{c}\text { The Activity Has Not } \\
\text { Been Performed } \\
\text { during My Time } \\
\text { as Owner (\%) }\end{array}$ \\
\hline Planting & 33 & 26 & 31 & 10 \\
$\begin{array}{c}\text { Cleaning } \\
\text { Thinning }\end{array}$ & 35 & 32 & 29 & 4 \\
$\begin{array}{c}\text { Wind-throw or } \\
\text { insect damage }\end{array}$ & 16 & 26 & 52 & 6 \\
$\begin{array}{c}\text { Other, e.g., final } \\
\text { felling or soil } \\
\text { scarification }\end{array}$ & 55 & 22 & 27 & 8 \\
\hline
\end{tabular}


Four out of ten respondents stated that they were familiar with the method of whole-tree harvesting in early thinnings and $18 \%$ claimed that they had previously undertaken such an operation on their forest property. Half of the respondents (51\%) stated that they had young dense forest stands that were in imminent need of cleaning or thinning operations, and 7\% did not know whether this was the case or not.

\subsection{Attitude towards Thinning in Young Dense Stands}

The analyses of respondents' attitudes towards whole-three harvest in early thinning were based on three different scenarios of economic consequences (see Section 2.2). There was a strong correlation between FFOs' answers on these respective scenarios, while correlations with some of the investigated FFO characteristics were small (Table 8 ). Results showed that the majority of the respondents (57\%) would absolutely, or at least in some cases, be willing to conduct a whole-tree harvest in early thinning even if the cost exceeded the income (Figure 1). If the income equaled or exceeded the cost of the operation, the proportion of respondents with positive answers increased to $74 \%$ and $85 \%$, respectively. Further, $52 \%$ of the respondents stated that they certainly would conduct such operations if it generated a net income (i.e., cost $<$ revenues from extracted biomass). Notably, only $6 \%$ stated that they absolutely not would conduct such operations if there was a net cost, while $3-4 \%$ would never do it even if the net income was zero or positive.

No significant difference in FFOs' attitude towards whole-three harvesting was found in relation to the respondents' gender $\left(\chi^{2}\right.$-test, $\left.p=0.791\right)$, age $(t$-test, $p=0.359)$, time as the forest owner $\left(\chi^{2}\right.$-test, $p=0.173$ ), association membership status ( $\chi^{2}$-test, $\left.p=0.981\right)$, main management objective, or owners' previous awareness about this particular management method $\left(\chi^{2}\right.$-test, $\left.p=0.654\right)$. A significant difference was found related to the respondent's forest size $\left(\chi^{2}\right.$-test, $\left.p=0.03\right)$ : the proportion of positive responses was larger among those with small properties (Table 9). However, the group with forest properties larger than 200 ha contained only 25 respondents. The respondents with an imminent need for cleaning or thinning in their forest were also significantly more often positive $(79 \%)$ compared to those without such needs $(69 \%)\left(\chi^{2}\right.$-test, $\left.p=0.022\right)$.

Table 8. Spearman's rho correlations between scenarios (survey questions 13-15) for whole-tree harvesting and FFO characteristics. Responses are coded in ascending order for all variables (e.g., negative to positive or low to high).

\begin{tabular}{|c|c|c|c|c|c|c|c|}
\hline Variable & $\begin{array}{l}\text { Distance } \\
\text { to Forest }\end{array}$ & $\begin{array}{c}\text { Duration } \\
\text { of } \\
\text { Ownership }\end{array}$ & $\begin{array}{l}\text { Forest } \\
\text { Size }\end{array}$ & $\begin{array}{c}\text { Level of } \\
\text { Self- } \\
\text { Employment }\end{array}$ & $\begin{array}{l}\text { Q13: Would } \\
\text { Harvest If } \\
\text { Cost > Income }\end{array}$ & $\begin{array}{l}\text { Q14: Would } \\
\text { Harvest If } \\
\text { Cost = Income }\end{array}$ & $\begin{array}{l}\text { Q15: Would } \\
\text { Harvest If } \\
\text { Cost < Income }\end{array}$ \\
\hline $\begin{array}{l}\text { Distance to } \\
\text { forest }\end{array}$ & 1.0 & $-0.10 *$ & 0.02 & $-0.23^{* *}$ & 0.05 & 0.07 & $0.11 *$ \\
\hline $\begin{array}{l}\text { Duration of } \\
\text { ownership }\end{array}$ & & 1.0 & 0.04 & 0.02 & -0.02 & -0.05 & $-0.11 *$ \\
\hline Forest size & & & 1.0 & -0.01 & -0.07 & $-0.14^{* *}$ & $-0.18^{* *}$ \\
\hline $\begin{array}{l}\text { Level of self- } \\
\text { employment }\end{array}$ & & & & 1.0 & $-0.12 * *$ & $-0.16^{* *}$ & $-0.13^{* *}$ \\
\hline $\begin{array}{l}\text { Q13: Would } \\
\text { harvest if } \\
\text { cost }>\text { income }\end{array}$ & & & & & 1.0 & $0.70 * *$ & $0.52 * *$ \\
\hline $\begin{array}{l}\text { Q14: Would } \\
\text { harvest if } \\
\text { cost = income }\end{array}$ & & & & & & 1.0 & $0.69 * *$ \\
\hline $\begin{array}{l}\text { Q15: Would } \\
\text { harvest if } \\
\text { cost < income }\end{array}$ & & & & & & & 1.0 \\
\hline
\end{tabular}




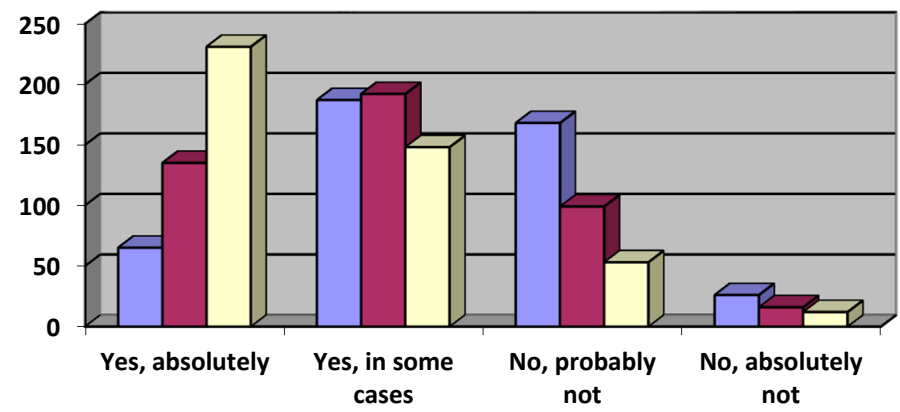

$\square$ Cost > Income

$\square$ Cost $=$ Income

$\square$ Cost $<$ Income

Figure 1. Forest owners' willingness to conduct whole-three harvesting in early thinning for three different scenarios.

Table 9. Percentage of FFOs with positive and negative attitudes to towards whole-tree harvest at thinning according to size of their forest.

\begin{tabular}{ccc}
\hline Forest Size (ha) & Positive (\%) & Negative (\%) \\
\hline$\leq 50$ & 78 & 22 \\
$51-200$ & 71 & 29 \\
$>200$ & 56 & 44 \\
\hline
\end{tabular}

Further, there was a strong tendency, although not statistically significant $\left(\chi^{2}\right.$-test, $\left.p=0.051\right)$, that respondents in Svealand were positive more often (86\%) than those in Götaland (72\%) and Norrland (71\%). Also, when comparing respondents based on the distance between their home and their forest, it was found that the most positive group was those who lived between 30 and $100 \mathrm{~km}$ away from their forest. In this group, $89 \%$ of the respondents were positive, compared to $72 \%$ in the other groups, but again the $p$-value was just above the level of significance $\left(\chi^{2}\right.$-test, $\left.p=0.054\right)$. There was also a tendency for self-employed forest owners who conducted many of the management activities themselves to be less positive towards whole-three harvesting $\left(\chi^{2}\right.$-test, $\left.p=0.055\right)$. In the group that conduct most management activities themselves, $66 \%$ were positive, while about three out of four respondents were positive in the groups with some or no self-employment. Finally, there was a trend for forest owners who had done this type of operation before to be positive more often $(82 \%)$ than those who had not $(73 \%)\left(\chi^{2}\right.$-test, $\left.p=0.078\right)$.

\subsection{Attitudes towards Active Management for Whole-Tree Harvesting in Early Thinnings}

The respondents were asked about their willingness to promote the development of forest stands suitable for whole-three harvesting in early thinning by reducing the number of early clearings in young stands and/or by leaving more stems when clearing is done. The majority $(60 \%)$ of the respondents responded positively to this and stated that, at least in some cases, they would be willing to do this. There was a significant difference between regions with respect to this matter $\left(\chi^{2}\right.$-test, $p=0.002)$, as forest owners in Svealand were more likely to respond positively than those in the northern (Norrland) and, especially, the southern (Götaland) regions (Table 10).

Table 10. FFOs' willingness to actively develop stands suitable for whole-tree harvesting in early thinning, e.g., through less intense cleaning.

\begin{tabular}{ccc}
\hline Region & Positive (\%) & Negative (\%) \\
\hline Götaland & 56 & 44 \\
Svealand & 78 & 22 \\
Norrland & 67 & 33 \\
\hline
\end{tabular}


There was also a significant difference in attitude between those who lived close to their forest property and those who lived further away $\left(\chi^{2}\right.$-test, $\left.p=0.032\right)$, with the latter more likely to give a positive response (Spearman's rho $=0.10, p=0.042$ ). In the group living more than $100 \mathrm{~km}$ from their property, $71 \%$ stated their willingness to promote stands for whole-tree harvesting, while the percentage among those who lived closest $(<30 \mathrm{~km})$ was $56 \%$. Further, $75 \%$ of those who prioritized nature conservation as their number one management objective were positive towards whole-tree harvesting. This was a significantly higher proportion than among those who prioritized financial returns or recreation $\left(\chi^{2}\right.$-test, $\left.p=0.004\right)$, whose respective share of positive responses were $54 \%$ and $61 \%$. Those who reported a higher degree of self-employment were significantly more negative than others $\left(\chi^{2}\right.$-test, $p=0.007$; Spearman's rho $\left.=-0.15, p=0.002\right)$. In this group the majority $(52 \%)$ stated that they probably or definitely would not consider such management, while in the other groups a clear majority (62-67\%) was positive towards it. Those who had previously undertaken whole-tree harvesting in early thinning on their property were also more likely to be positive (76\%) about this type of management. This was a significantly higher proportion compared to those with no previous experience of using the method ( $\chi^{2}$-test, $p=0.001$ ), for which the positive responses amounted to $57 \%$. Finally, those with an imminent need for cleaning were significantly more positive compared to those with no such needs $\left(\chi^{2}\right.$-test, $\left.p=0.009\right)$. For these two groups the respective proportions of respondents answering positively were $65 \%$ and $52 \%$.

There was a tendency for respondents with small properties $(<50 \mathrm{ha})$ to be more positive about this action than those with the largest properties $\left(\chi^{2}\right.$-test, $p=0.052$; Spearman's rho $=-0.13, p=0.009$ ). In the former group, $64 \%$ stated that they definitely or in some cases could implement this management objective, while in the latter group the majority (52\%) gave a negative response, i.e., they would probably or absolutely not do this.

There were no significant differences in relation to gender $\left(\chi^{2}\right.$-test, $\left.p=0.467\right)$, age ( $t$-test, $p=0.89$ ), duration of forest ownership ( $\chi^{2}$-test, $\left.p=0.625\right)$, association membership $\left(\chi^{2}\right.$-test, $\left.p=0.570\right)$, or prior awareness of the method $\left(\chi^{2}\right.$-test, $\left.p=0.318\right)$.

\subsection{Potential Negative Influences on FFOs' Attitude towards Whole-Tree Havesting in Early Thinnings}

It was found that the factors with the largest negative influence on many FFOs' attitudes towards whole-tree harvesting in early thinning were linked to whether, compared to traditional thinning, the method would lead to more soil damage, decrease the future timber volume, and/or cause more damage to the remaining trees. For these three factors, the majority of respondents stated that the influence would be negative or strongly negative (Table 11). A large proportion of the respondents were unable to say how the novelty (and thereby limited evidence of the outcomes) of this type of operation would affect their position, but most of those who had an opinion stated that it would have no or minor effect on their attitude. The majority (54\%) of the respondents considered that the need to create access roads at an earlier stage would have no or only a minor negative influence on their attitude. That more understory vegetation would be left in the forest would have a minor to moderate negative influence for the largest proportion of owners, which was also the case with respect to the potential for a temporary decrease in future growth. For both of these factors, less than one out of ten respondents considered it to have a strong negative influence on their attitude.

There were significant differences $(p<0.05)$ between how males and females responded to five out of seven factors, and strong tendency with a sixth (Table 12). A clear pattern, present for all seven factors, was that a higher proportion of females did not want to express an opinion about the issue. For some factors, the proportion was twice as high for this alternative compared to males. There were no major differences between genders concerning how large a proportion stated that the factor could have a negative or strongly negative influence, but on some issues females were more reluctant to say that it would have no or only a minor effect on their attitudes. 
Table 11. Distribution (\%) of forest owners' perception of how various hypothetical disadvantages associated with whole-tree harvesting in early thinnings would affect their attitude towards the method.

\begin{tabular}{|c|c|c|c|c|c|}
\hline Influential Factor & $\begin{array}{c}\text { No } \\
\text { Influence }\end{array}$ & $\begin{array}{l}\text { Minor } \\
\text { Negative } \\
\text { Influence }\end{array}$ & $\begin{array}{l}\text { Negative } \\
\text { Influence }\end{array}$ & $\begin{array}{l}\text { Strong } \\
\text { Negative } \\
\text { Influence }\end{array}$ & $\begin{array}{l}\text { Unable to } \\
\text { Say }\end{array}$ \\
\hline $\begin{array}{l}\text { Access roads need to be made } \\
\text { earlier compared to traditional } \\
\text { thinning }\end{array}$ & 28 & 26 & 21 & 3 & 22 \\
\hline $\begin{array}{l}\text { Causes a temporary decrease } \\
\text { in future growth compared to } \\
\text { traditional thinning }\end{array}$ & 13 & 30 & 28 & 8 & 21 \\
\hline $\begin{array}{l}\text { Decreases the future timber } \\
\text { volume compared to } \\
\text { traditional thinning }\end{array}$ & 11 & 14 & 27 & 29 & 19 \\
\hline $\begin{array}{l}\text { Causes more soil damage than } \\
\text { traditional thinning }\end{array}$ & 6 & 9 & 31 & 38 & 16 \\
\hline $\begin{array}{l}\text { Causes more damage to } \\
\text { remaining trees compared to } \\
\text { traditional thinning }\end{array}$ & 6 & 8 & 29 & 42 & 16 \\
\hline $\begin{array}{l}\text { It leaves more understory } \\
\text { vegetation than traditional } \\
\text { thinning with pre-cleaning }\end{array}$ & 17 & 26 & 25 & 9 & 24 \\
\hline It is an untested method & 15 & 18 & 14 & 5 & 48 \\
\hline
\end{tabular}

Table 12. Distribution (\%) of male and female forest owners' perception of how various hypothetical disadvantages associated with whole-tree harvesting in early thinnings would affect their attitude towards the method.

\begin{tabular}{|c|c|c|c|c|c|c|c|}
\hline \multirow[t]{2}{*}{ Influential Factor } & \multicolumn{2}{|c|}{$\begin{array}{l}\text { No to Minor } \\
\text { Influence }\end{array}$} & \multicolumn{2}{|c|}{$\begin{array}{c}\text { Negative to } \\
\text { Strong Influence }\end{array}$} & \multicolumn{2}{|c|}{ Unable to Say } & \multirow[t]{2}{*}{$\begin{array}{l}p \text {-Value } \\
\left(\chi^{2} \text {-test }\right)\end{array}$} \\
\hline & Male & Female & Male & Female & Male & Female & \\
\hline $\begin{array}{l}\text { Access roads need to be } \\
\text { made earlier compared to } \\
\text { traditional thinning }\end{array}$ & 62 & 36 & 21 & 31 & 17 & 33 & 0.000 \\
\hline $\begin{array}{c}\text { Causes a temporary decrease } \\
\text { in future growth compared to } \\
\text { traditional thinning }\end{array}$ & 45 & 39 & 37 & 33 & 18 & 28 & 0.054 \\
\hline $\begin{array}{l}\text { Decreases the future timber } \\
\text { volume compared to } \\
\text { traditional thinning }\end{array}$ & 27 & 21 & 57 & 52 & 16 & 27 & 0.019 \\
\hline $\begin{array}{l}\text { Causes more soil damage } \\
\text { than traditional thinning }\end{array}$ & 18 & 10 & 69 & 68 & 13 & 21 & 0.025 \\
\hline $\begin{array}{l}\text { Causes more damage to } \\
\text { remaining trees compared to } \\
\text { traditional thinning }\end{array}$ & 15 & 10 & 72 & 68 & 13 & 22 & 0.025 \\
\hline $\begin{array}{l}\text { It leaves more understory } \\
\text { vegetation than traditional } \\
\text { thinning with pre-cleaning }\end{array}$ & 48 & 30 & 34 & 34 & 18 & 36 & 0.000 \\
\hline It is an untested method & 35 & 28 & 20 & 17 & 45 & 55 & 0.148 \\
\hline
\end{tabular}




\section{Discussion}

This study investigated Swedish FFOs' perceptions of management and thinning operations in young dense forests and factors that could potentially affect their willingness to implement the whole-tree harvesting method for biomass extraction. There are significant opportunities to increase the extraction of forest biomass from Swedish forests [6,8], but the forest management and utilization of this biomass will be dependent on the individual decisions of FFOs who together own half of the country's forests. Understanding their attitudes towards forest management and, in this case, particularly whole-tree harvesting in young dense stands, is thus of great importance for the development and marketing of new services that they are willing to implement in their own forests. Increasing our knowledge of this is also important from a societal perspective since good forest management and a more efficient use of renewable resources will be vital for reaching the environmental goals that have been set on both national and international levels [4].

The results of this study show that, in general, the FFOs have a positive attitude towards this particular type of management, especially as long as the revenue from extracted biomass, at minimum, matches the costs. However, this study does not reveal their exact level of positivity. Furthermore, there were many who would be willing to implement whole-tree harvesting in dense stands even if it would result in a cost, as long as it does not exceed the cost of traditional thinning methods. Thus, FFOs' positive attitude towards extraction of more biomass from young dense stands is similar to their views on removal of logging residues after final-felling [23]. That the economic result of implementing whole-tree harvesting would affect the FFOs' attitude was expected since economic return is often found to be an important driver for performing forest management [24-27]. That only $6 \%$ would never consider undertaking whole-tree harvesting if it has an associated cost should thus be considered a positive sign for the future potential of this type of service.

There were few significant differences in attitudes towards whole-tree harvesting in young dense stands that could be linked to FFOs' characteristics, as only those with small forest holdings and those with an imminent need for cleaning were found to be positive more often. The former factor also tended to affect, to some extent, the FFOs' willingness to promote the development of dense stands suitable for whole-tree harvesting in early thinnings. A reason for the more positive attitudes among FFOs with small forest holding could potentially be that it better fits their current management practices, since earlier studies have shown that FFOs' with small forest holdings often have a more passive management strategy than others [28,29]. From the industry's perspective this may be considered challenging, since it would be more efficient to target incentives and marketing actions at FFOs with larger holdings. Establishing biomass-rich stands on larger properties would also mean that the operating costs for harvesting could be kept as low as possible, which in turn would make the service more attractive among FFOs in general.

Furthermore, geographical location, the distance between the FFOs' residence and the forest, their degree of self-employment and previous experience of whole-tree harvesting in young dense stands seemed to affect attitudes to some extent. In particular, these factors significantly affected owners' willingness to adjust their forest management in order to promote the development of forest stands suitable for biomass extraction with the whole-tree harvesting method. As Eggers et al. [29] noted, a longer distance to the forest hampers the FFOs' opportunities to visit and take care of their own forests and thus leads to different management strategies. FFOs who live in urban areas and are less dependent on forest income and amenities might also have a more distant relationship to the forest and be guided by other values and personal needs, which in turn affect their attitudes towards different management methods. For example, the availability of bio-fuel for personal use (e.g., firewood for house heating) will often be more valuable for those who live close to their forest land [15]. This could be a reason why those who lived close to their properties and those with a higher degree of self-employment were less positive about creating dense stands, as it might conflict with the traditional management practices they have undertaken so far. A very dense forest might also be considered less attractive or less accessible for recreational activities, which affect those who live close 
to the forest to higher degree. Thus, since non-resident owners were more positive they may be an interesting group to target with marketing of whole-tree harvesting in dense stands, especially since this group also tend to outsource more management activities [29], and so may be more receptive to new service offers.

Earlier studies have shown differences between male and female FFOs' activity with respect to forest management and timber sales $[19,28,29]$, as well as in their forest values and management objectives [15]. However, the results of this study showed no gender related differences concerning attitudes to implementing whole-tree harvesting in young dense stands, nor in willingness to actively promote the development of forests suitable for this type of biomass extraction. However, one difference was that female owners were more reluctant to express an opinion about whether the potential disadvantages of this novel thinning method would have a negative effect on their attitudes if they occurred. One possible reason for this could be that female owners in general are less experienced and feel more insecure in the role as foresters [28], and hesitate to take a stand on this issue as they may have a less clear picture of the practical implications of the hypothetical problems that were proposed.

No differences in attitude were found between members and non-members of forest owners' associations. This was somewhat surprising since previous studies have shown that members are more often production oriented and put higher value on forest income than non-members [30], and that they tend to choose different management strategies [29]. Neither did the FFOs' age or time as the forest owner seem to influence attitudes to any significant extent. This is in line with the findings of Eggers et al. [29], who argued that factors related to the owner per se have less influence on forest management than factors such as dependency on forest income and knowledge of forestry.

Considering the aspects that could potentially reduce FFO's willingness to implement the whole-tree harvesting method, it was clear that the minimizing damage in the forest is very important. This is in line with the results of Norin and Tosterud [23], who also found that soil damage caused by machines was the strongest argument for not extracting biomass after final-felling. According to Ahnlund Ulvcrona et al. [7], boom-corridor thinning could be one cost-effective method for biomass thinning in dense stands and, based on their evaluation, it has no apparent disadvantages compared traditional selective thinning methods. The main difference is that boom-corridor thinning leaves a more heterogeneous forest stand compared to traditional thinning and pre-commercial thinning. Thus, no matter whether whole-tree harvesting in young dense stands is achieved through boom-corridor thinning or other thinning schemes, there are few reasons to believe that increased forest damage would become a major problem during future implementation. In the short-term one of the main obstacles will probably be finding profitable business models for this type of service, which will affect the willingness of contractors and forest companies to offer it to FFOs.

This study has a few limitations. First, since the sample included few cases from the northern parts of Sweden, where a significant proportion of the young dense forest stands are currently located [8], it may not give a complete picture for the entire FFO population. As the sampling process was administered by an external organization, it is has not been possible to confirm whether the geographically skewed sample was just a random result or if there was a systematic error in the sampling process. However, the limited number of FFOs from Norrland in the sample was compensated for by a high response rate, which made it possible to separate this region in the analysis. Another limitation is that the respondents may not have fully understood the concept of whole-tree harvesting in young dense forest stands although it was described in the questionnaire. This is because the method is rather new, so few people have seen it in practice. Further, several of the survey questions measured FFO's attitudes on a four point scale, without a neutral alternative, which forced respondents to express a positive or negative opinion. Previous studies have shown that in such cases indifferent and neutral respondents tend to distribute randomly on each side, while ambivalent respondents tend to more often react negatively when a midpoint is omitted [31]. Thus, this type of scale may sometimes be questioned, although other studies have shown no major differences between scales with and without a midpoint [32]. However, for the objective of this study it was considered beneficial 
to leave out the neutral option in order to get more indicative answers and avoid a large share of neutral answers. The use of ordinal scales with few and labeled response options was also considered to make it easier for FFOs to answer and thereby promoting a higher response rate, although it to some extent also limited the types of analysis suitable for the data. For example, respondents were only classified as positive or negative regardless of how strong their opinions were, which means that the variation within each group may be large. Finally, based on communication with some respondents, there may also have been different perceptions among them of what constitutes a "dense" forest stand. One way to overcome this problem in future studies would be to include pictures or videos to describe the concepts and definitions.

As the methods for whole-tree harvesting in early thinning develop and the practice becomes more frequently used, future studies will also have better opportunities to investigate FFOs' attitudes towards it. This will allow more in-depth comparisons between those who have implemented it as part of their forest management and those who have refrained from doing so. From a societal perspective, it may also be of interest to investigate whether it would be beneficial to offer public support in terms of subsidies in order to encourage FFOs to increase biomass production through active forest management.

\section{Conclusions}

The study highlights the fact that the development of cost efficient harvesting techniques and working methods is important if the industry wants to increase the FFOs' willingness to engage in whole-tree harvesting in young dense forest stands and thereby increase the supply of biomass. In general, FFOs were positive towards implementing whole-tree harvesting in young dense stands, and often also willing to promote the development of suitable stands. The study also identified differences related to FFOs' characteristics, and this may help forest companies to target their initial marketing efforts towards the groups that are most positive, thus increasing the likelihood of successful market implementation of new services and methods for biomass extraction. However, it is important to note that more studies are needed in order to get a deeper and more nuanced understanding of FFOs' perceptions of management and thinning operations in young dense forest stands, and the factors that influences their opinions.

Author Contributions: Conceptualization, T.K., D.B. (David Bengtsson) and D.B. (Dan Bergström); methodology, T.K., D.B. (David Bengtsson) and D.B. (Dan Bergström); formal analysis, T.K. and D.B. (David Bengtsson); investigation, T.K. and D.B. (David Bengtsson); writing-original draft preparation, T.K.; writing-review and editing, T.K., D.B. (David Bengtsson) and D.B. (Dan Bergström); supervision, T.K. and D.B. (Dan Bergström); project administration, D.B. (Dan Bergström); funding acquisition, D.B. (Dan Bergström). All authors have read and agreed to the published version of the manuscript.

Funding: This study was conducted in the project SMALLWOOD, supported under the umbrella of ERA-NET Cofund ForestValue by Formas, Vinnova and Swedish Energy Agency. ForestValue has received funding from the European Union's Horizon 2020 research and innovation programme under grant agreement No. 773324.

Acknowledgments: The authors wish to thank the respondents and the reviewers for their valuable contribution to the completion of this paper.

Conflicts of Interest: The authors declare no conflict of interest. The funders had no role in the design of the study; in the collection, analyses, or interpretation of data; in the writing of the manuscript, or in the decision to publish the results.

\section{References}

1. Christiansen, L. Strukturstatistik: Statistik om Skogsägande 2017; Swedish Forest Agency: Jönköping, Sweden, 2018; pp. 1-36.

2. Joshi, S. Bruttoavverkning 2017; Swedish Forest Agency: Jönköping, Sweden, 2018; pp. 1-34.

3. Swedish Energy Agency. Energiläget 2019: En översikt; Swedish Energy Agency: Eskilstuna, Sweden, 2019; pp. 1-14. 
4. Ollikainen, M. Forestry in bioeconomy-Smart green growth for the humankind. Scand. J. For. Res. 2014, 29, 360-366. [CrossRef]

5. Börjesson, P.; Hansson, J.; Berndes, G. Future demand for forest-based biomass for energy purposes in Sweden. For. Ecol. Manag. 2017, 383, 17-26. [CrossRef]

6. De Jong, J.; Akselsson, C.; Egnell, G.; Gerhardt, K.; Löfgren, S.; Olsson, B. Realizing the energy potential of forest biomass in Sweden-How much is environmentally sustainable? For. Ecol. Manag. 2017, 383, 3-16. [CrossRef]

7. Ahnlund Ulvcrona, K.; Bergström, D.; Bergsten, U. Stand structure after thinning in 1-2 m wide corridors in young dense stands. Silv. Fenn. 2017, 51, 1-15. [CrossRef]

8. Fernandez-Lacruz, R.; Di Fulvio, F.; Athanassiadis, D.; Bergström, D.; Nordfjell, T. Distribution, characteristics and potential of bio-mass dense thinning forests in Sweden. Silv. Fenn. 2015, 49, 1-17.

9. Bergström, D.; Bergsten, U.; Nordfjell, T.; Lundmark, T. Simulation of geometric thinning systems and their time requirements for young forests. Silv. Fenn. 2007, 41, 137-147. [CrossRef]

10. Bergström, D. Techniques and Systems for Boom-Corridor Thinning in Young Dense Forests. Ph.D. Thesis, Swedish University of Agricultural Sciences, Umeå, Sweden, 2009.

11. Bergström, D.; Di Fulvio, F. Comparison of the cost and energy efficiencies of present and future biomass supply systems for young dense forests. Scand. J. For. Res. 2014, 29, 793-812. [CrossRef]

12. Bergström, D.; Di Fulvio, F. Studies on the use of a novel prototype harvester head in early fuel wood thinnings. Int. J. For. Eng. 2014, 25, 156-170.

13. Witzell, J.; Bergström, D.; Bergten, U. Variable corridor thinning-A cost-effective key to provision of multiple ecosystem services from young boreal conifer forests? Scand. J. For. Res. 2019, 34, 497-507. [CrossRef]

14. Haugen, K.; Karlsson, S.; Westin, K. New forest owners: Change and continuity in the characteristics of Swedish non-industrial private forest owners (NIPF owners) 1990-2010. Small Scale For. 2016, 15, 533-550. [CrossRef]

15. Nordlund, A.; Westin, K. Forest values and forest management attitudes among private forest owners in Sweden. Forests 2011, 2, 30-50. [CrossRef]

16. Weiss, G.; Lawrence, A.; Hujala, T.; Lidestav, G.; Nichiforel, L.; Nybakk, E.; Quiroga, S.; Sarvašová, Z.; Suarez, C.; Živojinović, I. Forest ownership changes in Europe: State of knowledge and conceptual foundations. For. Policy Econ. 2019, 99, 9-20. [CrossRef]

17. Karppinen, H.; Hänninen, H.; Horne, P. Suomalainen Metsänomistaja 2020; Natural Resources Institute Finland: Helsinki, Finland, 2020.

18. Favada, I.M.; Karppinen, H.; Kuuluvainen, J.; Mikkola, J.; Stavness, C. Effects of timber prices, ownership objectives, and owner characteristics on timber supply. For. Sci. 2009, 55, 512-523.

19. Kuuluvainen, J.; Karppinen, H.; Hänninen, H.; Uusivuori, J. Effects of gender and length of land tenure on timber supply in Finland. J. For. Econ. 2014, 20, 363-379. [CrossRef]

20. Krejcie, R.; Morgan, D. Determining sample size for research activities. Educ. Psychol. Meas. 1970, 30, 607-610. [CrossRef]

21. Gill, J.; Johnson, P.; Clark, M. Research Methods for Managers, 4th ed.; Sage Publications: Thousand Oaks, CA, USA, 2010.

22. Staal Wästerlund, D.; Kronholm, T. Family forest owners' commitment to service providers and the effect of association membership on loyalty. Small Scale For. 2017, 16, 275-293. [CrossRef]

23. Norin, K.; Tosterud, A. Enkät Visar att Skogsägare är Positiva till Grotuttag; Skogforsk: Uppsala, Sweden, 2009.

24. Ní Dhubháin, Á.; Cobanova, R.; Karppinen, H.; Mizaraite, D.; Ritter, E.; Slee, B.; Wall, S. The values and objectives of private forest owners and their influence on forestry behaviour: The implications for entrepreneurship. Small Scale For. 2007, 6, 347-357. [CrossRef]

25. Ederyd, M. Användning av Avverkningslikvider Bland Svenska Enskilda Skogsägare. Master's Thesis, Swedish University of Agricultural Sciences, Uppsala, Sweden, 2012.

26. Aguilar, F.X.; Cai, Z.; D'Amato, A.W. Non-industrial private forest owners' willingness-to-harvest: How higher timber prices influence woody biomass supply. Biomass Bioenergy 2014, 71, 202-215. [CrossRef]

27. Bashir, A.; Sjølie, H.K.; Solberg, B. Determinants of nonindustrial private forest owners' willingness to harvest timber in Norway. Forests 2020, 11, 60. [CrossRef]

28. Lidestav, G.; Berg Lejon, S. Harvesting and silvicultural activities in Swedish family forestry-Behavior changes from a gender perspective. Scand. J. For. Res. 2013, 28, 136-142. [CrossRef]

29. Eggers, J.; Lämås, T.; Lind, T.; Öhman, K. Factors influencing the choice of management strategy among small-scale private forest owners in Sweden. Forests 2014, 5, 1695-1716. [CrossRef] 
30. Berlin, C.; Lidestav, G.; Holm, S. Values placed on forest property benefits by Swedish NIPF owners: Differences between members in forest owners associations and non-members. Small Scale For. Econ. Manag. Policy 2006, 5, 83-96.

31. Weijters, B.; Cabooter, E.; Schillewaert, N. The effect of rating scale format on response styles: The number of response categories and response category labels. Int. J. Res. Mark. 2010, 27, 236-247. [CrossRef]

32. Leung, S.O. A comparison of psychometric properties of properties and normality in 4-, 5-, 6- and 11-point Likert scales. J. Soc. Serv. Res. 2011, 37, 412-421. [CrossRef]

Publisher's Note: MDPI stays neutral with regard to jurisdictional claims in published maps and institutional affiliations.

(C) 2020 by the authors. Licensee MDPI, Basel, Switzerland. This article is an open access article distributed under the terms and conditions of the Creative Commons Attribution (CC BY) license (http://creativecommons.org/licenses/by/4.0/). 